the volume that deal with Muslim contexts, there is a separate section of the book specifically on Arabic documentation, including letters from Ghadames in the Sahara, Mauritania, and the Swahili coast. Finally, there is a closing section containing two chapters that deal with the legacy of slavery in contemporary African societies, including two Soninke family biographies and memories of slavery in southern Niger. The editors present each section with a brief introduction.

Despite the considerable praise that I have for this volume, there are some weaknesses that deserve to be discussed. First, several of the maps in the volume could be much better, which is especially important for purposes of teaching. The illustrations, by contrast, are excellent. Second, there are very short bibliographies for each chapter, for reasons that are not really explained and do not seem warranted. There is no collective bibliography for the volume as a whole which thereby reduces its usefulness as a pedagogical tool. It is difficult to understand why this is the case since the book is already very long, and a bibliography would hardly have added to the length but would have increased its usefulness as a resource.

Another factor in assessing the book is the geographical and temporal coverage of the volume. There are parts of Africa that are not covered, which I think is to be expected in a collaborative project of this scope. This is not a weakness, in my opinion, but a challenge. Additional textual material and oral data certainly exist for Angola, South Africa, Mozambique, and many other parts of Africa. It can be expected that these accounts will further expand our understanding of the slave experience. Moreover, accounts of slavery in the contemporary world are also forthcoming and being studied in considerable depth, including sex slavery, child conscription for war, and other forms of slavery that demonstrate that slavery is not a product of the past but extends to the present.

The coverage in this volume includes numerous cases from Muslim areas, which accurately reflects an important division within Africa in the nineteenth and twentieth centuries. The volume also includes cases that are outside the Muslim sphere, as is certainly appropriate. One great contribution of the volume, nonetheless, is the considerable weight it gives to Islamic contexts, which thereby helps to correct an existing bias in the coverage of African history that often does not give sufficient coverage to this component of the past and thereby distorts our understanding of the influence of Islam in Africa today.

Paul Lovejoy

Department of History, York University 4700 Keele Street, Toronto $\mathrm{M}_{3} \mathrm{~J}_{\mathrm{I}} \mathrm{P}_{3}$, Ontario, Canada E-mail: plovejoy@yorku.ca

Bonded Labour and Debt in the Indian Ocean World. Ed. by Gwyn Campbell and Alessandro Stanziani. [Financial History, vol. 22.] Pickering \& Chatto, London [etc.] 2013. xiii, 240 pp. £60.00; \$99.00. doi:10.1017/ So020859015000085

This edited volume on bonded labour in the Indian Ocean rim is one of the latest contributions to a long row of books which appeared in the wake of the 2007 and $20 \mathrm{II}$ bicentenary commemorations of the abolition of the slave trade in the British Empire. 
The book is an important contribution because it demonstrates the huge variety of what I suggest calling "controlled labour" that existed in the various regions of the Indian Ocean from the beginning of the eighteenth century right into the twentieth. Therefore, the articles in the book do not simply elaborate another form of slavery but highlight debt bondage as a variation of bonded labour and, at the same time, as a specific form of strictly controlled labour within a highly diversifying labour market. This is particularly stressed by Isabelle Guérine's chapter on twentieth-century debt bondage in south Indian Tamil Nadu. She argues that, contrary to economic theory, which generally rejects bonded labour as well as slave labour as unproductive, local industrial agriculturists employed any form of labour that would maximize their profits. In the case of the three industries investigated in the volume, local capitalists encouraged bonded labour because it made the local workforce cheaper, easier to discipline, and to control. ${ }^{\mathrm{I}}$

In the introduction the editors point out that "there was considerable continuity, as well as change, in the transition from the older forms of debt-related bondage to the new ones that emerged with the forces accompanying the international economy that developed in the long nineteenth century, namely European colonialism and the more recent process of globalization" (p. 2). Bonded labour and debt bondage, in many cases ending up as hereditary slavery, is not a phenomenon of modern times; on the contrary, such forms had been established in different forms in various parts of the Indian Ocean world since ancient times. However, the growing industrial capitalism of the few Western countries and colonial capitalism based on the appropriation and extraction of capital in their imperial annexes transformed and reshaped the existing labour relationships which were based on rather customary relationships and transformed them into legalized institutions. This, in fact, strengthens the old narrative "from custom to contract". Also, in contrast to the transatlantic chattel slavery which depended on the capture and trafficking of humans, in the Indian Ocean world the majority of slaves seem to have originated from local debt bondage which is why in most cases debtors remained in their local environs.

High interest rates on credit, gambling debts, droughts, and famine were the frequent reasons why humans were indebted or were sold as slaves. In most cases the victims of men's indebtedness were women and children, as men sold both to reimburse their varying creditors. It is against this background that in some regions of the Indian Ocean world debt labour outnumbered slavery. However, what is actually missing in the introduction is a definition of slavery and slaves as well as debt bondage.

Despite the fact that one category might overlap the other and with boundaries also blurring in a few cases, the definition and the status of a slave as well as that of an indebted labourer seem to be taken for granted regardless of the various societies and polities of the Indian Ocean world. Yet, aside from this shortcoming, it has been nicely pointed out in the article by Bok-rae Kim that enslavement of people in Korea removed them from the population subject to taxation which is why some states tried to prohibit or at least to curb debt bondage and enslavement due to debts. It is this fiscal consideration which made the British Parliament pay $£_{22,000,000}$ compensation to the slave-owners in the British Empire after 1834 because in the long run a multiple sum would be returned by

I. The spectrum of labour control ranging from slavery to wage labour is the core argument of my own book on the slave trade and slavery in the Indian Ocean: Sabibs, Sklaven und Soldaten. Geschichte des Menschenhandels rund um den Indischen Ozean (Darmstadt, 2012), esp. pp. 19-23, 206-213. 
the increased amount of taxes paid by the millions of new taxpayers. A variation of such state intervention is elaborated on by Gwyn Campbell. In I865, the ruler of the Merina Empire on Madagascar emancipated i 50,000 privately owned slaves only to categorize them as members of a hereditary slave caste many of whom were employed in state projects.

Yet, despite the abolition of the slave trade and slavery in the British Empire, the prevalence of both increased during the nineteenth century. As Edward Alpers shows in his article, a fast-growing slave trade from the late eighteenth century substantially altered the mechanisms of pawnship in East Africa, eventually transforming it into an institution to procure slaves on a large scale. This interrelationship tightening the links between debt, pawn, and slavery was strongest along the East African coast and along the main trading routes into the hinterland. What is interesting is the fact that what was prevalent in some parts of East Africa did not exist or emerge in West African societies. The contributions of Ei Murakami and Bok-rae Kim confirm Alpers's observations, namely that in some regions of the Indian Ocean, debt bondage and slavery dramatically increased: in Korea, for example, from just I to about 50 per cent during the nineteenth century.

The effects of globalization, migration, agro-industrial production, and the concomitant growing demand for labourers brought about new forms of strict labour control ranging from allegedly "free" wage labour on the one side and slavery on the other. In some cases emancipation led to rather peculiar forms of new enslavement. The most prominent example is that of the "Prize Negroes": Africans liberated from ships in the Indian Ocean yet kept as confiscated property and transferred to the British government whose officials then forced them into contract labour. For the eastern Indian Ocean (Indonesian archipelago) James Warren in his article demonstrates that in the Zulu zone Westerners involved in the redemption of slaves often passed the accrued costs of liberation on to the freed slaves and therefore considered them indebted to themselves. The liberated slave was thus forced to work for the "advanced money" and the costs for his ship passage. In consequence, many former slaves became more dependent on their new "masters" than they had been before liberation. And in some cases slaves freed by Spanish warships were simply forced into the ships' crews.

It has been argued, including by one of the editors of the present volume, that indentured labour in fact was similar to slave labour ${ }^{2}-$ which is not the case by far. Just to mention a few substantial differences: first, indentured labourers possessed contracts which were of particular importance to the labourers when the terms of contract became negotiable in case of another period of indenture. Second, the living conditions of indentured labourers could be much worse than that of slaves as, in contrast to slaves, "coolies" had to pay for their clothing, medical care, and of course food. Consequently, many indentured labourers either had to work small plots of land or in case of the women, whose wages were generally half the amount of their male colleagues, work as prostitutes. It seems that in the case of indentured and bonded women, labour often meant sex work as well. This is highlighted, again, by Ei Murakami's article who demonstrates that the various colonial regimes in the Indian Ocean caused a demand for prostitutes to work where heavily increasing numbers of soldiers and migrant workers concentrated.

2. Gwyn Campbell, "Servitude and the Changing Face of Demand for Labour in the Indian Ocean World, c.I800-1900", conference paper; also see n. 50, p. I89 in the reviewed book. For a previous statement of the argument see Hugh Tinker, A New System of Slavery: The Export of Indian Labour Overseas, I830-1920 (London [etc.], 1974). 
In many cases it was Chinese and Japanese girls who were forced into sex labour, parents selling off their young females or receiving "advances", the capital, interest, and the costs of passage, lodging, clothing and food being deducted from the girls' earnings. Very often this put them in a position of permanent indebtedness. However, the question of whether these girls should be regarded as bonded labourers or as sex slaves, i.e. slaves in a juridical and not moral sense, has yet to be decided.

Due to the lack of space only half the contributions to the volume have been included in this review. All the articles, however, have a high quality which makes the book all the more valuable as the most recent contribution to a still ongoing debate on bonded labour, debt bondage, and slavery and, for that matter, on forms of controlled labour in a globalizing world market based on an increasing division of labour. The edited volume is a true collection of articles and deserves the utmost attention of scholars and students.

\section{Michael Mann}

The Institute of Asian and African Studies, Humboldt-Universität zu Berlin Unter den Linden 6, 10099 Berlin, Germany E-mail: michael.mann@asa.hu-berlin.de

Huberman, Michael. Odd Couple. International Trade and Labor Standards in History. Yale University Press, New Haven [etc.] 20I2. xii, 237 pp. £45.00. doi:10.1017/S002085901 5000097

International trade and labour standards do not seem to mesh well in the current age of neoliberal globalization. Today's protagonists of free trade object to any social chapter in a trade agreement, while many defenders of the welfare state are sceptical of further liberalization of cross-border trade and investment. This was not always the case.

In his account of pre-World-War-I globalization, economist and historian Michael Huberman reminds us that many social reformers like Émile Vandervelde, a Belgian leader of the Labour and Socialist International, supported free trade on the condition of the adoption of what Huberman designates as a "labor compact", i.e. a set of regulations on working hours, the minimum work age, and on social insurance. This conditional support for free trade by the labour movement before I9I4 lets Huberman claim that trade, not ideas or domestic struggles, was the main driver of the labour compact which in turn laid the foundation for the modern welfare state. With the help of econometrics and country case studies, he marshals support for this claim. The case studies cover three typical variants of the pre-W-W-I labour compact: a small open economy in the labour-abundant "Old World" (Belgium), a land-rich region of recent settlement (Canada) and a "New World" country harboring enclaves of cheap labor (Brazil). The book is divided into two parts: how globalization caused the labor compact and how the labor compact affected trade.

Huberman does not deny the domestic pressure for labour legislation; however, as a driving factor for this pressure he identifies volatility in employment and wages due to globalization. External trade pressures transmitted the labor compact internationally: "States had an incentive to abide by labor agreements they had negotiated with trading 